\title{
Meningkatkan Prestasi Belajar Agama Hindu Melalui Implementasi Model Pembelajaran Kooperatatif Tipe Tgt (Team Game Turnament)
}

\author{
Ni Nengah Watis ${ }^{1 *}$ \\ ${ }^{1}$ SMP Negeri 2 Singaraja, Singaraja Indonesia
}

\begin{abstract}
Abstrak
Penelitian ini dilaksanakan di Kelas IX-13 SMP Negeri 2 Singaraja pada smester ganjil tahun pelajaran 2016/2017, dengan tujuan adalah untuk meningkatkan prestasi belajar Pendidikan Agama Hindu siswa kelas IX-13 SMP Negeri 2 Singaraja pada semester ganjil Tahun pelajaran 2016/2017 melalui Implementasi Model Pembelajaran Kooperatif Type Team Game Turnament (TGT). Metode pengumpulan datanya melalui tes prestasi belajar, yang selanjutnya dianalisis dengan menggunakan metode deskriptif kuantitatif. Data disajikan dalam bentuk rata-rata prestasi belajar dan prosesntase ketuntasan belajar. Hasil penelitian ini menunjukkan data awalnya rata-rata hasil belajar siswa hanya 72,58 dengan siswa yang tuntas sebanyak 44,22 \%. Pada siklus I setelah dilaksanakan implementasi strategi pembelajaran kooperatif tipe TGT ternyata terjadi kenaikan prestasi belajar yang ditandai dengan rata-rata 78,24 ketuntasan belajar 75,00 \%. Dan Setelah memperbaiki kekurangan-kekurangan yang masih terjadi pada siklus I, maka pada siklus II memperoleh data prestasi belajar meningkat menjadi rata-rata 79,06 ketuntasan belajar 86,11 \%. Kesimpulan yang diperoleh dari penelitian ini adalah Implementasi Strategi Pembelajaran Kooperatif Type Team Game Turnamen (TGT) dapat meningkatkan prestasi belajar siswa pada kelas IX-13 smester ganjil tahun pelajaran $2016 / 2017$
\end{abstract}

Keywords:

Kooperatif TGT, prestasi belajar

\section{PENDAHULUAN}

Agama memiliki peran yang amat penting dalam kehidupan umat manusia. Agama menjadi pemandu dalam upaya mewujudkan suatu kehidupan yang bermakna, damai dan bermartabat. Menyadari peran agama amat penting bagi kehidupan umat manusia maka internalisasi agama dalam kehidupan setiap pribadi menjadi sebuah keniscayaan, yang ditempuh melalui pendidikan baik pendidikan di lingkungan keluarga, di lembaga pendidikan formal maupun nonformal serta masyarakat.

Pendidikan Agama dimaksudkan untuk membentuk peserta didik menjadi manusia yang beriman dan bertakwa kepada Tuhan Yang Maha Esa dan berakhlak mulia serta peningkatan potensi spritual. Akhlak mulia mencakup etika, budi pekerti, dan moral sebagai perwujudan dari pendidikan Agama. Peningkatan potensi spritual mencakup pengenalan, pemahaman, dan penanaman nilai-nilai keagamaan, serta pengamalan nilai-nilai tersebut dalam kehidupan individual ataupun kolektif kemasyarakatan. Peningkatan potensi spritual tersebut pada akhirnya bertujuan pada optimalisasi berbagai potensi yang dimiliki manusia yang aktualisasinya mencerminkan harkat dan martabatnya sebagai makhluk Tuhan. Dengan demikian maka, Pendidikan Agama Hindu adalah usaha yang dilakukan secara terencana dan berkesinambungan dalam rangka mengembangkan kemampuan peserta didik untuk memperteguh keimanan dan ketakwaan kepada Tuhan Yang Maha Esa dan berakhlak mulia, serta peningkatan potensi spiritual sesuai dengan ajaran agama Hindu.

Proses pembelajaran Pendidikan Agama Hindu, hendaknya di desain secara sistematis, agar dapat mencapai bertujuan; (1)menumbuhkembangkan dan meningkatkan kualitas Sradha dan Bhakti melalui pemberian, pemupukan, penghayatan dan pengamalan ajaran agama, (2)membangun insan Hindu yang dapat mewujudkan nilai-nilai Moksartham Jagathita dalam kehidupannya. Desain pembelajaran yang cocok berkaitan dengan tujuan dimaksud adalah pembelajaran yang membawa kondisi pembelajaran dengan pemanfaatan partisipasi siswa secara maksimal. Pembelajaran berorientasi kepada aktivitas,

* Corresponding author.

E-mail Addresses: - Ninghwatis88@gmail,.com (Ni Nengah Watis) 
kreativitas secara maksimal dari siswa. Pembelajaran seperti ini adalah pembelajaran yang berpusat pada siswa (Student Centered). Keberhasilan dalam pelaksanaan pendekatan pembelajaran berpusat kepada siswa terletak pada kemampuan guru memilih dan memanfaatkan strategi pembelajaran.

Kondisi pembelajaran pendidikan Agama Hindu di kelas saat ini, masih diwarnai oleh pendekatan ekspositoris dan otoritas metodologis yang begitu kaku. Paradigma ini semakin menjauhkan Pendidkan Agama Hindu dari misi dan visinya sebagai media strategis dalam pembentukan dan pelatihan peserta didik sebagai warga negara yang demokratis dan bertanggung jawab. Masalah lain adalah semakin keringnya pembelajaran dari creative dialoque, yang justru membuat siswa semakin terbatas untuk belajar dan membelajarkan dirinya. Kondisi ini semakin memperkuat opini masyarakat bahwa Pendidikan Agama Hindu adalah pelajaran yang tidak terlalu perlu pada era perkembangan Ilmu Pengetahuan dan Tehnologi Moderen saat ini.

Permasalahan tersebut banyak dikontribusi oleh kurangnya pemahaman dan keterampilan guru Pendidikan Agama Hindu dalam pemanfaatan strategi, metode dan model pembelajaran, sehingga pembelajaran yang dilakukannya lebih berorietasi pada ketuntasan materi, bukan pada kebermaknaan pembelajaran bagi peserta didik. Akibatnya tujuan dan kepentingan belajar peserta didik terabaikan selama pembelajaran berlangsung, karena mereka hanya dijadikan objek pembelajaran, sehingga motivasi, aktivitas siswa dalam proses pembelajaran menjadi semakin menurun, dan serta merta mengakibatkan nilai hasi belajar siswa sangat rendah.

SMP Negeri 2 Singaraja, adalah sebuah sekolah yang berada di wilayah kecamatan Busiungbiu Kabupaten Buleleng. Dalam pembelajaran Pendidikan Agama Hindu, mengalami permasalahan seperti umumnya yang dialami pada kelas-kelas yang telah disampaikan. Kualitas pembelajaran Pendidikan Agama Hindu pada sekolah ini sangat rendah. Indikator yang digunakan untuk menilai kondisi pembelajaran pada sekolah ini adalah; hasil belajar yang diperoleh setelah dikonfirmasikan dengan KKM (Kriteria Ketuntasan Minimal) yang ditentukan oleh guru. Hasil belajar Pendidikan Agama Hindu yang diperoleh pada smester sebelumnya, dari KKM yang ditentukan 75,00 baru mencapai rata-rata; 69,55 dengan daya serap 69,55\% dan prosentase ketuntasan belajar (siswa yang berhasil tuntas sesuai KKM) baru mencapai $44,74 \%$. Kategori hasil belajar yang diraih termasuk sangat rendah, dan harus segera ditanggulangi, mengingat pentingnya Pendidikan Agama Hindu membentuk generasi yang berakhlak mulia. Berdasarkan permasalahan tersebut maka peneliti melaksanakan penelitian yang berjudul "Meningkatkan Prestasi Belajar Agama Hindu Pada Siswa Kelas IX-13 SMPN 2 Singaraja Pada Smester Ganjil Tahun Pelajaran 2016/2017 Melalui Implementasi Model Pembelajaran Kooperatatif Tipe TGT (Team Game Turnament)"

Dari uraian latar belakang permasalahan tersebut dapat disampaikan bahwa rumusan permasalahan pada penelitian ini adalah; apakah prestasi belajar Pendidikan Agama Hindu Siswa Kelas IX-13 SMPN 2 Singaraja Pada Smester Ganjil Tahun Pelajaran 2016/2017 dapat ditingkatkan melalui implementasi Model Pembelajaran Kooperatatif Tipe TGT (Team Game Turnament)?

Solusi penanggulangan permasalahan mengacu kepada fungsi Pendidikan Agama Hindu tersebut, pembelajaran Pendidikan Agama Hindu didesain untuk dapat memberikan kesempatan kepada siswa, menumbuhkembangkan kemampuannya secara maksimal. Siswa bisa diberi kemandirian untuk belajar dengan memanfaatkan aneka sumber belajar yang ada. Dengan demikian pembelajaran Pendidikan Agama Hindu menuntut keaktifan siswa sedangkan guru hanya sebagai fasilitator untuk membantu siswa dalam pembelajaran. Sejalan dengan pandangan tersebut maka pembelajaran kooperatif tampaknya merupakan strategi yang paling sesuai. Dalam pembelajaran kooperatif siswa harus mampu untuk bekerja sama dalam kelompok kecil yang heterogen, adanya ketergantungan positif (saling membutuhkan), saling membantu, dan saling memberikan motivasi. Pada saat belajar kooperatif sedang berlangsung, guru terus melakukan pemantauan melalui obsevasi dan penekanan belajar tidak hanya pada penyelesaian tugas tetapi juga hubungan interpersonal. Begitu banyaknya tipe strategi kooperatif yang dapat dimanfaatkan dalam menanggulangi kualitas pembelajaran. Pada penelitian ini kooperatif yang di manfaatkan untuk menangulangi kulaitas pembelajaran adalah tipe Team Game Turnament (TGT). Dilihnya strategi ini untuk menanggulangi permasalahan adalah karena strategi ini memiliki keunggulan diantaranya; TGT merupakan model pembelajaran dengan memainkan permainan dengan anggota-amggota tim lain untuk memperoleh skor bagi tim mereka masing-masing. Setiap kelompok terdiri dari 5 sampai 6 orang peserta didik yang memiliki kemampuan, jenis kelamin dan suku kata atau ras yang berbeda. Guru menyajikan materi, dan peserta didik bekerja dalam kelompok mereka masing-masing. Model pembelajaran TGT terdiri dari lima langkah tahapan, yaitu tahap penyajian kelas (class precentation), belajar dalam kelompok (teams), permaianan (games), pertandingan dan turnamen (tournament), dan penghargaan kelompok (team recognition).

Kelebihan model pembelajaran kooperatif tipe TGT adalah sebagai berikut: Model TGT tidak hanya membuat peserta didik yang cerdas (berkemampuan akademis tinggi) lebih menonjol dalam 
pembelajaran, tetapi peserta didik yang berkemampuan akademi lebih rendah juga ikut aktif dan mempunyai peranan yang penting dalam kelompoknya. Dengan model pembelajaran ini, akan menumbuhkan rasa kebersamaan dan saling menghargai sesama anggota kelompoknya. Dalam model pembelajaran ini, membuat peserta didik lebih bersemangat dalam mengikuti pelajaran. Karena dalam pembelajaran ini, guru menjanjikan sebuah penghargaan pada peserta didik atau kelompok terbaik. Dalam pembelajaran peserta didik ini membuat peserta didik menjadi lebih senang dalam mengikuti pelajaran karena ada kegiatan permainan berupa tournamen dalam model ini.

Tujuan pelaksanaan penelitian ini adalah untuk meningkatan prestasi belajar Pendidikan Agama Hindu Siswa Kelas IX-13 SMP Negeri 2 Singaraja Pada Smester Ganjil Tahun Pelajaran 2016/2017 melalui Implementasi Model Pembelajaran Kooperatatif Tipe Team Game Turnament (TGT).

Pelaksanaan penelitian diupayakan agar dapat bermanfaat dalam pengembangan profesi keguruan. Dengan demikian manfaat penelitaian ini diharapkan dapat dirasakan bagi berbagai kalangan seperti; Bagi siswa, prestasi belajar dapat ditingkakann mengingat Implementasi Model Pembelajaran Kooperatatif Tipe Team Game Turnament (TGT) ini memiliki keunggulan yang sangat cocok untuk menanggulangi permasalahan yang sedang dihadapi. Bagi Guru, hasil penelitian ini dapat dipergunakan sebagai alternative solusi penanggulangan permasalahan pembelajaran, dan secara serta merta mengindikasikan profesionalitas guru dalam pengelolaan dan peningkatan kualitas pembelajaran. Bagi sekolah, hasil penelitian dapat dipergunakan sebagai refrensi dalam menanggulangi permasalahan rendahnya outpot dan outcome pendidikan di sekolah ini.

\section{METODE PENELITIAN}

Penelitian ini selama 2 (dua ) siklus, masing-masing siklus terdiri dari 3 (tiga) kali pertemuan, Jika penelitian telah terlaksana dalam 2 (dua) kali siklus, maka bagaimanapun hasilnya penelitian harus dihentikan. Subjek penelitian ini adalah Siswa Kelas IX-13 SMP Negeri 2 Singaraja, Kecamatan Buleleng berjumlah 38 orang. Obyek penelitian ini adalah peningkatan prestasi belajar, setelah Implementasi Model Pembelajaran Kooperatatif Tipe Team Game Turnament (TGT) secara konsisten. Penelitian ini dilakukan pada smester ganjil tahun pelajaran 2016/2017 yakni dari bulan September sampai dengan Desember 2016.

Metode yang digunakan untuk mengumpulkan data penelitian ini adalah melalui test prestasi belajar siswa yang dilaksanakan setiap akhir proses pembelajaran. Setelah data dalam penelitian ini terkumpul, selanjutnya dianalisis menggunakan analisis statistik deskriptif. Untuk mengetahui tingkat keberhasilan yang dapat dicapai pada sebuah tindakan, maka perlu ditentukan kriteria keberhasilan yang dapat diamati dari indikator-indikator ketercapaian. Kriteria keberhasilan penelitian ini dapat diukur dari ketercapaian peningkatan prestasi belajar siswa, setelah pelaksanaan Implementasi Model Pembelajaran Kooperatatif Tipe Team Game Turnament (TGT). Penelitian ini dikatakan berhasil apabila prosentase rata-rata prestasi belajar siswa baik pada siklus I maupun pada siklus II telah mencapai sama atau lebih dengan KKM yang ditentukan, KKM mata Pelajaran Pendidikan Agama Hindu adalah 75 dan prosentase ketuntasan telah mencapai diatas 85\%. Namun jika siklus II telah selesai dilaksanakan ternyata indikator keberhasilan dimaksud tidak tercapai, maka penelitian harus dihentikan. Untuk hal ini maka peneliti harus menghentikan penelitian dan atas kegagalan ini peneliti merekomendasi peneliti lainnya untuk tidak menggunkan strategi ini dalam penelitian lainnya.

\section{ANALISIS DAN PEMBAHASAN}

Gambaran kondisi awal yang menjadi latar belakang penelitian ini dapat dijelaskan sebagai berikut; rata-rata hasil belajar siswa baru mencapai 69,55 dengan daya serap, 69,55 \% serta ketuntasan belajar yang baru mencapai $44,74 \%$ (dari 38 siswa subjek penelitian, hanya 17 orang siswa yang baru mencapai ketuntasan belajar). Secara rinci penyajian gambaran hasil belajar awal siswa pada kelas IX-13 SMP Negeri 2 Singaraja pada pembelajaran Pendidikan Agama seperti terlihat pada Table 1. 


\begin{tabular}{rcccc}
\hline \multirow{2}{*}{ No } & \multicolumn{3}{c}{ Rata-rata Nilai .... } & Jumlah \\
Nomponen & Pengetahuan & $\begin{array}{c}\text { Unjuk } \\
\text { Kerja }\end{array}$ & Potofolio & $0-100$ \\
\cline { 2 - 5 } Rata-Rata & 66,92 & 74,56 & 81,94 & 72,58 \\
Jml Siswa Tuntas & 8 & 23 & 34 & 17 \\
Jml Siswa Tidak Tuntas & 28 & 13 & 2 & 19 \\
Ketuntasan & $22,22 \%$ & $63,89 \%$ & $94,44 \%$ & $47,22 \%$ \\
\hline
\end{tabular}

Hasil Pelaksanaan penelitian Siklus I, yang diawali dengan tahapan perencanaan dengan kegiatan adalah : Menyusun Rencana Pelaksanaan Pembelajaran (RPP) yang akan dilaksanakan melalui Implementasi Model Pembelajaran Kooperatatif Tipe Team Game Turnament (TGT). Menentukan waktu pelaksanaan Implementasi Model Pembelajaran Kooperatatif Tipe Team Game Turnament (TGT) dalam action di kelas IX-13 SMP Negeri 2 Singaraja. Mengorganisaasikan materi, media, dan sumber belajar terkait dengan Implementasi Model Pembelajaran Kooperatatif Tipe Team Game Turnament (TGT).Merencanakan skenario pembelajaran. Skenario pembelajaran dalam RPP disesuikan dengan tujuan, materi, tingkat perkembangan siswa, waktu yang tersedia, sistematiknya Model Pembelajaran Kooperatatif Tipe Team Game Turnament (TGT), menaruh siswa dalam posisi sentral, mengikuti perubahan strategi pendidikan dari pengajaran ke pembelajaran sesuai standar proses pembelajaran.

Tahap pelaksanaan proses pembelajaran dilaksanakan dengan pengelolaan kelas sesuai dengan Implementasi Model Pembelajaran Kooperatatif Tipe Team Game Turnament (TGT). Langkah-langkah pembelajaran yang dilakukan menyesuaikan strategi pembelajaran yakni; Penyajian Kelas (Class Presentations), Belajar dalam Kelompok (Teams), Permainan (Games), Pertandingan atau Lomba (Tournament), Penghargaan Kelompok (Team Recognition).

Pengamatan yang dilaksanakan oleh teman sejawat untuk ikut mengamati kebenaran pelaksanaan tahapan pembelajaran yang menggunakan Model pembelajaran kooperatif tipe TGT. Pengamatan menggunakan lembar pengamatan yang telah disusun sebelumnya. Berikut ini disajikan hasil pengamatan terhadap hasil belajar siswa setelah implementasi Model pembelajaran kooperatif tipe TGT, disajikan pada Tabel 2. berikut.

Tabel 2. Nilai Prestasi Belajar Siklus I

\begin{tabular}{rcccc}
\hline \multirow{2}{*}{ No } & \multicolumn{3}{c}{ Rata-rata Nilai ..... } & NILAI AKHIR \\
Rentang ... & Keterangan \\
\cline { 2 - 5 } Romponen & Pengetahuan & $\begin{array}{c}\text { Unjuk } \\
\text { Kerja }\end{array}$ & Potofolio & $0-100$ \\
Ratata & $\mathbf{7 2 , 2 2}$ & $\mathbf{7 9 , 4 4}$ & $\mathbf{8 9 , 0 8}$ & $\mathbf{7 8 , 2 4}$ \\
Jml Siswa Tuntas & 15 & 29 & 35 & 27 \\
Jml Siswa Tidak Tuntas & 21 & 7 & 1 & 9 \\
Ketuntasan & $\mathbf{4 1 , 6 7 \%}$ & $\mathbf{8 0 , 5 6 \%}$ & $\mathbf{9 7 , 2 2 \%}$ & $\mathbf{7 5 , 0 0 \%}$ \\
\hline
\end{tabular}

Keunggulan-keunggulan dari pelaksanaan siklus I ini dapat disajikan sebagai berikut; Telah terjadi peningkatan motivasi belajar bagi siswa, Siswa muali terbiasa belajar berkelompok, Siswa mulai mau menggali pengetahuan sendiri terkait materi yang sedang diajarkan,

Kelemahan Siklus I, Selain keunggulan-keunggulan tersebut, penelitian ini juga memiliki kelemahan-kelemahan seperti; Masih ada siswa yang belum mau menyesuaikan diri, Beberapa siswa enggan melaksanaka tugas yang diberikan oleh guru, Terlihat beberapa siswa yang terbiasa diceramahi, atau diberikan materi oleh gurunya merasa kebingungan dalam menentukan materi essensial,

Berdasarkan analisis data kuantitatip, selanjutnya dikonfirmasikan dengan indikator keberhasilan penelitian, maka hasil penelitian siklus I ini belum memenuhi indikator keberhasilan yang ditentukan. Pada bagian sebelumnya telah disampaikan bahwa indikator keberhasilan adalah apabila prosentase ratarata prestasi belajar siswa baik pada siklus I maupun pada siklus II telah mencapai sama atau lebih dengan KKM yang ditentukan, dan prosentase ketuntasan telah mencapai diatas $85 \%$. Walaupun hasil 
belajar siswa telah mencapai KKM yang ditentukan yakni telah berhasil mencapai rata-rata 78,24 namun dari sis ketuntasan belajar baru mencapai, 75,00 \%. Dengan demikian maka diputuskan bahwa penelitian ini dilanjutkan pada siklus II, dengan memperbaiki kelemahan-kelemahan penelitian siklus I ini.

Hasil refleksi siklus I menyatakan masih adanya kelemahan-kelemahan dalam penelitian ini yang harus segera ditanggulangi, maka seperti pelaksanaan siklus sebelumnya, pelaksanaan siklus II ini pun diawali dengan tahap perencanaan. Perencanaan siklus II ini, dilaksanakan dalam upaya menanggulangi kelemahan siklus I demi kesempurnaan proses kegiatan dan hasil penelitian selanjutnya. Hasil tes prestasi belajar siswa siklus II akan dibahas pada refleksi II. Untuk lebih jelasnya, berikut ini disajikan hasil pengumpulan data hasil belajar siswa melalui kegiatan observasi disajikan pada Tabel 3. sebagai berikut.

Tabel 3 Nilai Hasil Belajar Siswa Siklus II

\begin{tabular}{|c|c|c|c|c|c|c|}
\hline \multirow{2}{*}{ No } & \multirow{2}{*}{ Komponen } & \multicolumn{3}{|c|}{ Rata-rata Nilai ..... } & \multirow{2}{*}{$\begin{array}{c}\begin{array}{c}\text { Nilai Akhir } \\
\text { Rentang }\end{array} \\
0-100\end{array}$} & \multirow{2}{*}{ Keterangan } \\
\hline & & Pengetahuan & $\begin{array}{l}\text { Unjuk } \\
\text { Kerja }\end{array}$ & Potofolio & & \\
\hline & Rata-Rata & 73,61 & 79,72 & 89,31 & 79,06 & \\
\hline & Jml Siswa Tuntas & 16 & 30 & 35 & 31 & \\
\hline & ml Siswa Tidak Tuntas & 20 & 6 & 1 & 5 & \\
\hline & Ketuntasan & $44,44 \%$ & $83,33 \%$ & $97,22 \%$ & $86,11 \%$ & \\
\hline
\end{tabular}

Keunggulan-keunggulan dari pelaksanaan siklus II ini dapat disajikan sebagai berikut; Siswa betulbetul telah terbiasa belajar secara mandiri, Siswa muali memahami materi-materi essensial yang mesti dipahami dari hasil-hasil diskusi yang telah dilaksanakan, Dengan memberikan penghargaan kepada siswa yang berhasil dan memberikan hukuman kepada siswa yang masih belum berhasil, maka siswa menunjukkan usaha-usaha agar mereka bisa, Ketuntasan belajar dapat ditingkatkan, dan pendidikan agama tidak lagi sebagai mata pelajaran yang tidak perlu dipelajari,

Selain keunggulan-keunggulan tersebut, penelitian ini juga memiliki kelemahan-kelemahan seperti; Masih terdapat siswa yang belum tuntas walaupun sudah diberikan kesempatan dan bimbingan, untuk itu anak tersebut perlu penangan secara berkelanjutan terkait dengan perkembangan psikologisnya, Pada kondisi-kondisi tertentu pembelajaran dengan strategi ini kurang efektif, misalnya saat jam terakhir (menjelang pulang) sehingga perlu betul-betul mendapat perhatian yang serius bagi guru

Berdasarkan analisis data kuantitatip, selanjutnya dikonfirmasikan dengan indikator keberhasilan penelitian, maka hasil penelitian siklus II ini telah melampaui indikator keberhasilan dimaksud. Untuk itu maka penelitian dihentikan dan dinyatakan telah berhasil.

Untuk mempertegas hasil penelitian dan melihat perkembangan hasil belajar yang diperoleh setelah implementasi Model pembelajaran kooperatif tipe TGT maka berikut ini disajikan rekapitulasi hasil. Dari rekapitulasi ini akan diketahui peningkatan-peningkatan yang terjadi. Rekapitulasi dimaksud dapat dilihat pada Tabel 4 berikut.

Tabel 4. Rekap Hasil Belajar

\begin{tabular}{rcccccc}
\hline \multirow{2}{*}{ No } & \multicolumn{3}{c}{ Rata-rata Nilai ..... } & \multicolumn{2}{c}{ Gain Skor } & Keterangan \\
\cline { 2 - 6 } & Awal & Siklus I & Siklus II & 1 & 2 \\
Rata-Rata & $\mathbf{7 2 , 5 8}$ & $\mathbf{7 8 , 2 4}$ & $\mathbf{7 9 , 0 6}$ & $\mathbf{5 , 6 6}$ & $\mathbf{0 , 8 2}$ \\
Jml Siswa Tuntas & 17 & 27 & 31 & 0 & 0 \\
Jml Siswa Tidak Tuntas & 19 & 9 & 5 & 36 & 0 \\
Ketuntasan \% & $\mathbf{4 7 , 2 2}$ & $\mathbf{7 5 , 0 0}$ & $\mathbf{8 6 , 1 1}$ & $\mathbf{0 , 0 0}$ & $\mathbf{0 , 0 0}$ \\
\hline
\end{tabular}

Berikut ini juga disampaikan rekapitulasi rata-rata, dan ketuntasan belajar siswa pada pembelajaran pendidikan agama hindu, dalam bentuk grafik seperti berikut ini. 


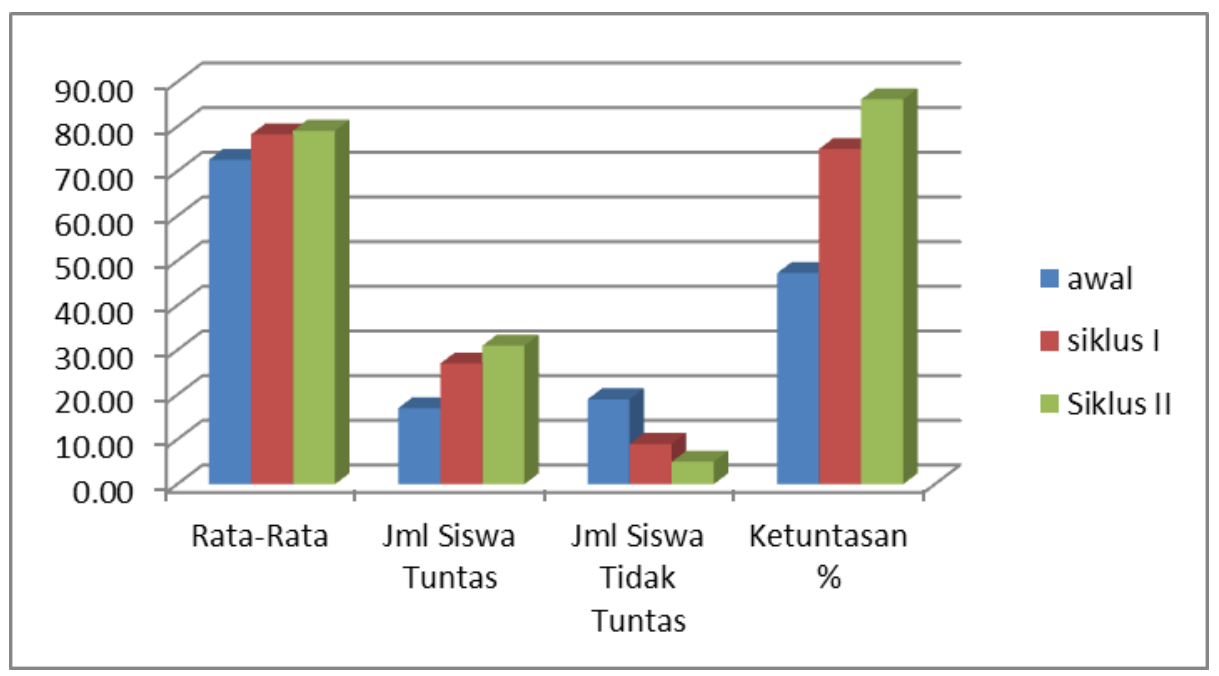

Gambar 1. Rekapitulasi Rata-Rata, Dan Ketuntasan Belajar Siswa Pada Pembelajaran Pendidikan Agama Hindu

Dari data pada tabel tersebut dapat diketahui bahwa implementasi Model pembelajaran kooperatif tipe TGT memicu adanya perkembangan hasil belajar siswa yang sangat positif, perkembangan tertinggi ada pada perkembangan 2. Hal ini dapat dipahami bahwa akibat kelemahan pada siklus I dilaksanakan penguatan-penguatan pada siklus II termasuk memberikan reward dan funishment. Dengan demikian maka langkah-langkah memberikan reward dan funishment kepada siswa berdampak positif terhadap perkembangan prestasi belajar siswa, untuk itu langkah ini mestinya terus dilaksanakan.

Hasil tes prestasi belajar di siklus I telah menemukan efek utama bahwa penggunaan metode/strategi pembelajaran tertentu akan berpengaruh terhadap hasil belajar siswa yang dalam hal ini adalah Model pembelajaran kooperatif tipe TGT. Hal ini sesuai dengan hasil meta analisis metode pembelajaran yang dilakukan oleh Soedomo (dalam Puger, 1989/1990) yang menyatakan bahwa metode/startegi pembelajaran yang diterapkan oleh seorang guru berpengaruh terhadap hasil belajarnya.

Kendala yang masih tersisa yang perlu dibahas adalah hasil belajar yang dicapai pada siklus I ini belum memenuhi harapan sesuai dengan tuntutan indikator keberhasilan penelitian terutama pada ketuntasan belajar klasikal yakni 85\%. Oleh karenanya upaya perbaikan lebih lanjut masih perlu diupayakan sehingga perlu dilakukan perencanaan yang lebih matang untuk siklus selanjutnya.

Hasil yang diperoleh dari tes prestasi belajar di siklus II menunjukkan bahwa kemampuan siswa dalam mengikuti pelajaran sudah cukup baik. Ini terbukti dari rata-rata nilai siswa mencapai 83,97 Hasil ini menunjukkan bahwa Model pembelajaran kooperatif tipe TGT telah berhasil meningkatkan kemampuan siswa menempa ilmu sesuai harapan. Model pembelajaran kooperatif tipe TGT merupakan model yang cocok bagi siswa apabila guru menginginkan mereka memiliki kemampuan berkreasi, berargumentasi, mengeluarkan pendapat secara lugas, bertukar pikiran, berargumentasi, mengingat penggunaan metode ini adalah untuk memupuk kemampuan intelektual siswa, mendorong siswa untuk mampu menemukan sendiri, menempatkan siswa pada posisi sentral dan mengupayakan agar siswa tidak belajar dengan menghafal. Hasil penelitian ini ternyata telah memberi efek utama bahwa model yang diterapkan dalam proses pembelajaran berpengaruh secara signifikan terhadap hasil belajar siswa. Temuan ini membuktikan bahwa guru sudah tepat memilih metode dalam melaksanakan proses pembelajaran karena pemilihan metode merupakan hal yang tidak boleh dikesampingkan. Hal ini sejalan pula dengan temuan-temuan peneliti lain seperti yang dilakukan oleh Inten (2004) dan Puger (2004) yang pada dasarnya menyatakan bahwa metode pembelajaran yang diterapkan berpengaruh terhadap prestasi belajar siswa.

Melihat perbandingan nilai awal, nilai siklus I dan nilai siklus II, terjadi kenaikan yang signifikan, yaitu dari rata-rata nilai awal adalah 72,58 naik di siklus I menjadi 78,24 dan di siklus II naik menjadi 79,06. Kenaikan ini rata-rata hasil belajar ini diikuti dengan ketuntasan belajar yang awalnya adalah 47,22 \% menjadi 75,00 \% pada silus I, dan pada siklus II naik menjadi 86,11\%. Kenaikan ini adalah efek dari upaya-upaya yang maksimal yang dilaksanakan peneliti demi peningkatan mutu pendidikan dan kemajuan pendidikan khususnya di kelas IX-13 SMP Negeri 2 Singaraja, Kecamatan Buleleng, Kabupaten Buleleng 


\section{KESIMPULAN}

Simpulan penelitian ini adalah bahwa; Implementasi Model Pembelajaran Kooperatatif Tipe Team Game Turnament (TGT) dapat meningkatkan prestasi belajar Pendidikan Agama Hindu Siswa kelas IX-13 SMP Negeri 2 Singaraja Smester Ganjil Tahun Pelajaran 2016/2017.

Temuan yang sudah disimpulkan dari hasil penelitian, dalam upaya mencapai tujuan penelitian menjadi dasar disampaikannya saran-saran sebagai berikut: Bagi guru; apabila mengalami permasalahan yang sama dengan permasalahan yang sedang ditanggulangi maka implementasi strategi pembelajaran ini merupakan alternatif pemecahannya, mengingat strategi ini telah terbukti dapat meningkatkan kerjasama, berkreasi, bertindak aktif, bertukar informasi, mengeluarkan pendapat, bertanya, berargumentasi dan lain-lain.

Bagi peneliti: walaupun penelitian ini sudah dapat membuktikan efek utama dari Implementasi Model Pembelajaran Kooperatatif Tipe Team Game Turnament (TGT) dalam meningkatkan prestasi belajar, sudah pasti dalam penelitian ini masih ada hal-hal yang belum sempurna dilakukan, oleh karenanya kepada peneliti lain yang berminat meneliti topik yang sama untuk meneliti bagian-bagian yang tidak sempat diteliti.

Bagi pemerhati pendidikan: agar selanjutnya melaksanakan penguatan-penguatan, terutama memfasilitasi kegiatan-kegiatan yang bersifat inovatif sehingga penjaminan mutu pendidikan dapat berlangsung secara konsisten dan berkesinambungan.

\section{DAFTAR PUSTAKA}

Arikunto, Suharsimi; Suhardjono; Supardi. 2006. Penelitian Tindakan Kelas. Jakarta: PT Bumi Aksara.

Arimbawa, P. A. dan I W. Santyasa, N. K. Rapi. 2017. "Strategi Pembelajaran Guru Fisika: Relevansinya Dalam Pengembangan Motivasi Belajar Dan Prestasi Belajar Siswa". Wahana Matematika Dan Sains: Jurnal Matematika, Sains, Dan Pembelajarannya, Vol. 11 No. 1, April 2017.

Binawati , Ni Wayan S dan I Wayan Rasna.2013. "Pembelajaran Kontekstual Agama Hindu Untuk Membangun Generasi Muda Berbudi Pekerti Luhur". Jurnal Ilmu Sosial dan Humaniora ISSN: 23032898 Vol. 2, No. 2, Oktober 2013.

Depdiknas. 2011. Membimbing Guru dalam Penelitian Tindakan Kelas. Jakarta: Pusat Pengembangan Tenaga Kependidikan Badan Pengembangan Sumber Daya Manusia Pendidikan dan Menjaminan Mutu Pendidikan.

Dewiyanti, Ni Kd. dan I Kt Adnyana P., I W. Wiarta. 2018. Pengaruh Model Pembelajaran Team Games Tournament (Tgt) Berbantuan Media Permainan Ular Tangga Terhadap Hasil Belajar Matematika. Jurnal Ilmiah Pendidikan dan Pembelajaran P-ISSN : 1858-4543 E-ISSN : 2615-6091 PPs Universitas Pendidikan Ganesha JIPP, Volume 2 Nomor 1 April 2018.

Dewi, Qurrota \& I Nyoman Suardana,I Made Suwenten, Penerapan Model Pembelajaran Kooperatif Tipe TGT (teams Games Tournament) Untuk Meningkatkan Motivasi dan Hasil Belajar Peserta Didik. Jurnal Pendidikan Kimia Indonesia Volume 1, Nomor 2, 2017.

Marianti dan Ratnawati Susanto (2017). Pengaruh Model Cooperative Learning Tipe Teams Games Tournament (TGT) Terhadap Kecerdasan Interpersonal Pada Mata Pelajaran IPS. Jurnal Ilmiah Sekolah Dasar. Vol.1 (4) pp. 260-269.

Nurman, Muhammad. 2006."Pengaruh Penggunaan Metode Pembelajaran Inkuiri dan Ekspositori Terhadap Sikap Politik Berdemokrasi dan Prestasi belajar Siswa Pada Pembelajaran PPKn di SMA (Studi Eksperimen tentang Pengaruh Metode Pembelajaran Terhadap Sikap Politik Berdemokrasi dan Prestasi Belajar PPKn Siswa di SMA NW Pancor - Lombok Timur). Tesis (tidak diterbitkan) Program Pascasarjana IKIP Negeri Singaraja.

Intaran, I Nyoman.2018. "Implementasi Model Pembelajaran Inkuiri dengan Berbantuan Media Gambar untuk Meningkatkan Prestasi Belajar Agama Hindu". JEAR, Vol. 2, No. 1, Tahun 2018, pp. 1-12 
Kariyana , I Kadek. 2014. Implementasi Pembelajaran Kooperatif TGT untuk Meningkatkan Aktivitas dan Hasil Belajar Dribbling Sepakbola. Penjaskesrek Fok Universitas Pendidikan Ganesha, Kampus Tengah Undiksha.

Kunandar. 2008. Langkah Mudah Penelitian Tindakan Kelas Sebagai Pengembangan Profesi Guru. Jakarta: Rajawali Pers.

Purwandari, Amanda dan Dyah Tri Wahyuningtyas (2017). Eksperimen Model Pembelajaran Teams Games Tournament (Tgt) Berbantuan Media Keranjang Biji-Bijian Terhadap Hasil Belajar Materi Perkalian Dan Pembagian Siswa Kelas II SDN Saptorenggo 02. Jurnal Ilmiah Sekolah Dasar. Vol.1 (3) pp. 163-170.

Putri , Dewi Siswanti dan Mawardi. 2017. “The Applıcatıon of Teams-Games-Tournament (TGT) To Increase Students' Actıveness And Learning Outcomes”. Jurnal Pendidikan dan Pengajaran, 50 (2), July 2017, 60-68 Universitas Kristen Satya Wacana, Salatiga, Indonesia.

Setiawan , Y. Z. dan, D. O. Rachmawati, I.Suswandi. 2016. "Pengaruh Motivasi Belajar Dan Lingkungan Belajar Terhadap Prestasi Belajar Fisika Kelas X Sma Negeri Di Kecamatan Mendoyo Tahun Ajaran 2014/2015". Jurnal Wahana Matematika dan Sains, Volume 9, Nomor 2, Oktober 2016.

Sudimahayasa, Nyoman. 2015. Penerapan Model Pembelajaran TGT untuk Meningkatkan Hasil Belajar, Partisipasi, dan Sikap Siswa Jurnal Pendidikan dan Pengajaran, Jilid 48, Nomor 1-3, April 2015, hlm. 45-53

Suhardjono. 2010. Pertanyaan dan Jawaban di Sekitar Penelitian Tindakan Kelas dan Penelitian Tindakan Sekolah. Malang: Cakrawala Indonesia.

Supardi, 2005. Pengembangan Profesi dan Ruang Lingkup Karya Ilmiah. Jakarta: Depdiknas.

Syaodih Sukmadinata, Nana. 2007. Metode Penelitian Pendidikan, Bandung: Remaja Rosda Karya.

Udin, S.W. 1997. Teori Belajar dan Model-Model Pembelajaran. Depdikbud: Jakarta.

Wojowasito. 1982. Kamus Umum Lengkap Inggris Indonesia - Indonesia Inggris. Malang: Delta Citra Grafindo. 